\title{
ANALISIS EFEKTIFITAS DAN EFEK SAMPING PENGGUNAAN OFF-LABEL RUTE PEMBERIAN DARI NIFEDIPINE SEBAGAI TOKOLITIK PADA PARTUS PRETERM IMMINENS DI RUMAH SAKIT MAKASSAR
}

\author{
Suhartina Hamzah ${ }^{1}$, Marianti A. Manggau ${ }^{1}$, Nasruddin AM $^{2}$ \\ ${ }^{1}$ Fakultas Farmasi, Universitas Hasanuddin, Makassar \\ ${ }^{2}$ Rumah Sakit Ibnu Sina, Makassar
}

Kata Kunci :

Ancaman partus preterm, tokolitik, skor bishop, baumgarten

\begin{abstract}
ABSTRAK
Penelitian ini dilakukan di RSUP Dr. Wahidin Sudirohusodo, RSUD. Labuang Baji, RSIA Sitti Khadijah dan Klinik Sitti Khadijah Makassar dari April hingga Juli 2017 bertujuan untuk mengidentifikasi efektifitas dan efek samping penggunaan Nifedipine sebagai tokolitik pada Ancaman Partus Preterm. Terdapat 35 pasien yang terdaftar dalam penelitian. Jenis penelitian ini merupakan penelitian Observasional non eksperimen dengan AnalisisDeskriptif. Alat penetapan standar yang digunakan untuk mengidentifikasi efektifitas dan efek samping adalah Guideline Tokolitik tahun 2011, dan skor penilaian Bishop dan Baumgarten. Hasil penelitian ini adalah sebanyak 35 pasien ditemukan, efektifitas Nifedipine dalam menunda persalinan prematur dalam waktu $2 \times 24$ jam adalah sebanyak 33 pasien dengan persentase sebesar $94,28 \%$. Sedangkan efek samping yang paling umum ditemukan adalah lemas sebanyak 4 pasien dengan persentase sebesar $11,42 \%$.
\end{abstract}

\section{PENDAHULUAN}

Partus preterm merupakan masalah penting dalam dunia kesehatan khususnya dibidang obstetrik karena baik di Negara berkembangmaupun Negara maju penyebab morbiditas dan mortalitas neonatus adalah bayi yang lahir prematur.World Health Organization (WHO) menyatakan bahwa sekitar 60-80\% morbiditas dan mortalitas neonatal di seluruh dunia disebabkan oleh persalinan prematur dan sekitar 6-18\% kejadiannya di Indonesia. Di Indonesia angka kematian bayi masih sangat tinggi, yaitu 34/1000 kelahiran hidup dan sekitar $57 \%$ kematian tersebut terjadi pada umur dibawah 1 bulan atau neonatus. $36 \%$ dari kematian neonatus disebabkan oleh inflamasi. Sedangkan, 23\% kasus disebabkan oleh asfiksia, 7\% kasus disebabkan oleh kelainan bawaan, 27\% kasus disebabkan oleh bayi kurang bulan dan Bayi Berat Lahir Rendah (BBLR), serta 7\% kasus oleh sebab lain menurut Depkes RI (1).

http://dx.doi.org/10.20956/mff.v $21 \mathrm{i} 3.6861$

Korespondensi

Marianti A Manggau

mariantimanggau@unhas.ac.id

Copyright

(C) 2017 Majalah Farmasi

Farmakologi Fakultas

Farmasi · Makassar

Diterbitkan tanggal

29-12-2017

Dapat Diakses Daring Pada: http://journal.unhas.ac.id/i ndex.php/mff
Partus preterm adalah persalinan dengan usia kehamilan kurang dari 37 minggu atau berat bayi kurang dari 2500 gram. Pada persalinan ini, bayi prematur mengalami gangguan tumbuh kembang organ vital yang menyebabkan belum mampu untuk hidup di luar kandungan sehingga mengalami kegagalan adaptasi yang dapat menimbulkan morbiditas bahkan mortalitas yang tinggi menurut POGI (2).

Tokolitik merupakan agen farmakologis dan terapi yang digunakan dalam mencegah kelahiran prematur, merelaksasi miometrium uterus dan menghambat kontraksi uterus sehingga dapat memperpanjang masa kehamilan dan mengurangi komplikasi neonata. Tokolitik beraksi melalui berbagai mekanisme untuk menurunkan availabilitas ion kalsium intraseluler yang akan menghambat interaksi aktin-myosin menurut Protocols Tocolytic (3).

Agen Tokolitik yang digunakan dalam praktek klinis digolongkan menjadi 5 bagian :Betamimetics, Calcium channel blockers, Oxytocins receptor antagonist, Prostaglandin synthetase inhibitors dan Magnesium sulfat menurut Protocols Tocolytic (3)

Obat yang digunakan sebagai tokolisis adalah Nifedipine dengan dosis 5-10 mg. Nifedipine dapat diberikan sublingual setiap 15-20 menit dalam 3 dosis, dan 10-20 mg yang dapat diberikan melalui mulut/oral selama 4-6 jam untuk persalinan prematur yang diberikan bersamaan dengan kortikosteroid. Manfaat kortikosteroid antenatal adalahuntuk pematangan paru janin, mencegah sindrom gangguan pernapasan, perdarahan intraventrikulardan kematian pada janin Rekomendasinya adalah betametason $12 \mathrm{mg}$ I.M setiap 24 jam dalam 2 dosis atau deksametason 6 mg I.M setiap 12 jam dalam 4 dosis, untuk wanita hamil antara usia kehamilan 26-34 minggu yang beresiko untuk bersalin prematur dalam 7 hari ke depan menurut Dipiro (4).

Dosis yang pernah dilakukan pada uji klinis adalah 10 mg sublingual setiap 15-20 menit selama 1 jam pertama, hingga kontraksi berhenti, kemudian dilanjutkan dengan nifedipine lepas lambat 60$160 \mathrm{mg} /$ hari tergantung pada kontraksi dan kondisi pasien (5).

Pemberian obat melalui rute sublingual merupakan pemberian obat yang diletakkan dibawah lidah di mana obat akan larut dan diserap ke aliran darah melalui permukaan ventral lidah dan dasar mulut. Tujuannya supaya efek yang diinginkan lebih cepat karena pembuluh darah di bawah lidah merupakan pusat dari sakit sehingga 
kerusakan obat pada saluran cerna dan metabolisme di dinding usus dan hati dapat dihindari (tidak melewati vena porta). Dalam hal permeabilitas, daerah rongga mulut lebih permeabel dari bukal/daerah pipi.Obat cepat masuk ke sirkulasi sistemik dan tidak mengalami first-pass metabolism (tingkat pertama). Absorpsi obat melalui rute sublingual adalah 3-10 kali lebih besar dari rute oral.Rute pemberian oral merupakan rute pemberian obat yang paling umum digunakan.Obat melalui rute yg paling kompleks dan lama sampai pada organ target.Absorpsi obat melalui saluran cerna (lambung/usus halus), memasuki sirkulasi portal dan obat mengalami metabolisme tingkat pertama (first-pass metabolism) di hati menurut Neha Narang (5).

Obat off-label merupakan obat diluar indikasi yang tertera dalam label atau diluar persetujuan oleh lembaga izin edar seperti Badan POM dan FDA (Food and Drug Administration). Obat yang telah disetujui oleh FDA atau BPOM akan mendapat label "approved" yang berisi informasi tentang cara dan dosis penggunaan berdasarkan hasil uji klinis. Salah satu alasan penggunaan obat off-label adalah kurangnya respon klinis pada pengobatan sebelumnya, intoleransi/kontraindikasi dengan alternatif lain seperti tersedianya obat yang disetujui sesuai indikasi serta pasien dengan pengobatan alternatif karena alasan klinis atau logistic menurut Burkle (7).

Adapun Klasifikasi dari Obat Off-label antara lain : Off-label usia (jika digunakan diluar rentang usia yang telah disetujui, Off-label dosis (jika obat yang diberikan dengan dosis lain dari yang tercantum pada izin edar/izin penjualan), Off-label indikasi (jika digunakan diluar indikasi yang tertera pada leaflet, Off-label kontraindikasi (jika menimbulkan kontraindikasi saat diberikan kepada pasien yang usianya tidak sesuai dengan peruntukan obatnya, dan Off-label rute pemakaian (jika digunakan diluar prosedur mengenai cara pemakaian yang seharusnya (8).

Hingga saat ini belum dilakukanpenelitian yang melihat hubungan antara pemberian oral nifedipine dengan melihat efektivitas serta efek sampingnya. Adapun efektivitas yang diukur adalah berkurangnya kontraksi uterus, sedangkan efek samping yang diukur adalah adanya penurunan tekanan darah, sakit kepala, udem, konstipasi dan lemas.

\section{METODE PENELITIAN}

Jenis penelitian ini merupakan penelitian Observasional non eksperimen dengan Analisis Deskriptif. Waktu penelitian dilaksanakan pada periode bulan Mei - Juli tahun 2017 dan lokasi penelitian di Rumah Sakit Umum Pusat Dr. Wahidin Sudirohusodo, Rumah Sakit Ibu \& Anak Sitti Khadijah, Rumah Sakit Umum Daerah Labuang Baji, dan Klinik Sitti Khadijah Makassar.

Bahan penelitian untuk mengkaji efektifitas Nifedipine berupa buku status pasien meliputi informasi umum pasien (usia, berat badan, tingkat pendidikan, pekerjaan), regimen terapi (jenis obat, dosis pemberian dan aturan pemakaian), nilai laboratorium serta kondisi klinis pasien.

Populasi sampel adalah pasien yang mendapat terapi tokolitik yaitu Nifedipine di RSUP Dr. Wahidin Sudirohusodo Makassar, RSIA Sitti Khadijah, RSUD Labuang Baji, dan Klinik Sitti Khadijah Makassar. Sampel adalah pasien ibu hamil dengan ancaman partus preterm yang dirawat inap di RSUP Dr. Wahidin Sudirohusodo Makassar, RSIA Sitti Khadijah, RSUD Labuang Baji, dan Klinik Sitti Khadijah Makassar periode Mei - Juli tahun 2017.Data inklusi yang dipilih adalah (1) Pasien ibu hamil <37 minggu yang mengalami kontraksi uterus, (2) Pasien ibu hamil yang normotensif/tekanan darah normal, (3) Pasien yang tidak mengkonsumsi obat antihipertensi dan obat lain, (4) Pasien yang bersedia menjadi sampel penelitian. Data kriteria eksklusijika :(1) Pasien ibu hamil yang memilki riwayat hipertensi dan hipotensi, (2) Pasien yang mengkonsumsi obat antihipertensi/obat lain, (3) Pasien yang tidak bersedia menjadi sampel penelitian.

Obat yang akan dievaluasi adalah obat yang digunakan pada terapi ancaman persalinan prematur meliputi obat Nifedipine di RSUP Dr. Wahidin Sudirohusodo Makassar, RSIA Sitti Khadijah, RSUD Labuang Baji, dan Klinik Sitti Khadijah Makassar

\section{Pengambilan Data}

Pengambilan data dilakukan dengan menggunakan buku status pasien yang tersedia di ruang rawat inap di RSUP Dr. Wahidin Sudirohusodo Makassar, RSIA Sitti Khadijah, RSUD Labuang Baji, dan Klinik Sitti Khadijah Makassar, yang mencakup data pasien meliputi usia, berat badan, pendidikan dan pekerjaan, serta nilai hasil laboratorium pasien dengan ancaman persalinan prematur. Data kemudian dimasukkan dalam lembaran pengumpul data dan kekurangan data dari buku status pasien dilengkapi dengan melihat catatan perawat, dengan melihat langsung kondisi pasien, dan bila perlu memperoleh data/informasi dari pasien atau keluarga pasien/care giver pasien.

Hasil Efektifitas terapi tokolitik akan dinilai dengan keberhasilan menunda persalinan selama 2 × 24 jam. Jika tokolitik berhasil, pasien dirawat sampai 2 hari bebas kontraksi.

\section{HASIL DAN PEMBAHASAN}

\begin{tabular}{|c|c|c|}
\hline Karakteristik Pasien & $n$ & $f(\%)$ \\
\hline \multicolumn{3}{|l|}{ Usia ibu (tahun) } \\
\hline $20-35$ tahun & 20 & 57,14 \\
\hline $36-45$ tahun & 15 & 42,86 \\
\hline \multicolumn{3}{|l|}{ Gravidarum } \\
\hline Primipara & 3 & 8,57 \\
\hline Multipara & 32 & 91,42 \\
\hline \multicolumn{3}{|l|}{ Riwayat abortus } \\
\hline Ya & 3 & 8,57 \\
\hline Tidak & 32 & 91,42 \\
\hline \multicolumn{3}{|l|}{$\begin{array}{l}\text { Riwayat persalinan } \\
\text { prematur }\end{array}$} \\
\hline Ya & 5 & 14,28 \\
\hline Tidak & 30 & 85,71 \\
\hline \multicolumn{3}{|l|}{ Berat badan (kg) } \\
\hline$<50$ & 10 & 28,57 \\
\hline$\geq 50$ & 25 & 71,42 \\
\hline \multicolumn{3}{|l|}{ Pendidikan } \\
\hline SD & 5 & 14,28 \\
\hline SMP & 7 & 20 \\
\hline SMA & 13 & 65 \\
\hline DIPLOMA & 5 & 14,28 \\
\hline S1 & 5 & 14,28 \\
\hline Jumlah & 35 & \\
\hline
\end{tabular}


Tabel 1 menunjukkkan karakteristik pasien dengan ancaman persalinan prematur yang dirawat inap di Rumah Sakit Dr. Wahidin Sudirohusodo Makassar, Rumah Sakit Umum Daerah Labuang Baji, RSIA Sitti Khadijah, dan Klinik Sitti Khadijah Makassar. Terdapat 35 pasien dengan ancaman persalinan prematur. Kelompok usia yang berusia $20-35$ tahun sebanyak 20 orang (57.14\%)dan usia $36-45$ tahun sebanyak 15 orang (42.86\%). Kelompok berat badan $<50 \mathrm{~kg}$ berjumlah 10 responden $(28.57 \%)$ dan $>50 \mathrm{~kg}$ berjumlah terbanyak yaitu 25 responden (71.42\%). Jumlah gravidarum terbanyak yaitu primipara 3 orang $(8.57 \%)$ dan multipara sebanyak 32 orang (91.42\%). Untuk riwayat abortus terbanyak adalah yang tidak memiliki riwayat sebanyak 3 orang $(8.57 \%)$ dan yang memiliki riwayat abortus sebanyak 32 orang $(91.42 \%)$. Untuk riwayat persalinan prematur terbanyak yaitu yang tidak memiliki riwayat persalinan prematur sebanyak 30 orang (85.71\%) dan yang memiliki riwayat persalinan prematur sebanyak 5 orang (14.28\%). Untuk pendidikan terakhir, yang paling banyak adalah tingkat SD yaitu sebanyak 5 orang (14.28\%), SMP 7 orang (20\%), SMA yaitu sebanyak 13 orang (65\%), diploma dan S1 masing-masing sebanyak 5 orang $(14.28 \%)$.

\begin{tabular}{|c|c|c|c|c|c|c|c|c|}
\hline \multirow{4}{*}{ Kasus } & \multicolumn{8}{|c|}{ Kontraksi (menit/detik) } \\
\hline & \multicolumn{4}{|c|}{ Pre-terapi } & \multicolumn{4}{|c|}{ Post Terapi } \\
\hline & \multirow{2}{*}{$\begin{array}{l}\text { Lama } \\
\text { kontraksi } \\
\text { (menit) }\end{array}$} & \multirow[b]{2}{*}{$\begin{array}{l}\text { Durasi } \\
\text { (detik) }\end{array}$} & \multicolumn{2}{|c|}{ I (3 x 10 mg/8 jam) } & \multicolumn{2}{|c|}{ II (3 x $10 \mathrm{mg} / 8 \mathrm{jam})$} & \multicolumn{2}{|c|}{ III (3 x $10 \mathrm{mg} / 8$ jam) } \\
\hline & & & $\begin{array}{c}\text { Lama } \\
\text { kontraksi } \\
\text { (menit }\end{array}$ & $\begin{array}{l}\text { Durasi } \\
\text { (detik) }\end{array}$ & $\begin{array}{c}\text { Lama } \\
\text { kontraksi } \\
\text { (menit }\end{array}$ & $\begin{array}{l}\text { Durasi } \\
\text { (detik) }\end{array}$ & $\begin{array}{c}\text { Lama } \\
\text { kontraksi } \\
\text { (menit }\end{array}$ & $\begin{array}{l}\text { Durasi } \\
\text { (detik) }\end{array}$ \\
\hline 1 & $2 \times 10$ & $15-20$ & $2 \times 10$ & $15-20$ & $1 \times 10$ & $10-15$ & $1 \times 10$ & $10-15$ \\
\hline 2 & $3 \times 10$ & $15-20$ & $2 \times 10$ & $20-25$ & $1 \times 10$ & $10-15$ & 0 & 0 \\
\hline 3 & $3 \times 10$ & $20-25$ & $3 \times 10$ & $15-20$ & $2 \times 10$ & $20-25$ & $1 \times 10$ & $20-25$ \\
\hline 4 & $2 \times 10$ & $15-20$ & $2 \times 10$ & $15-20$ & 0 & 0 & 0 & 0 \\
\hline 5 & $2 \times 10$ & $15-20$ & $2 \times 10$ & $15-20$ & 0 & 0 & 0 & 0 \\
\hline 6 & $3 \times 10$ & $15-20$ & $2 \times 10$ & $20-25$ & $2 \times 10$ & $10-15$ & 0 & 0 \\
\hline 7 & $2 \times 10$ & $15-20$ & $2 \times 10$ & $15-20$ & $1 \times 10$ & $10-15$ & 0 & 0 \\
\hline 8 & $3 \times 10$ & $15-20$ & $2 \times 10$ & $20-25$ & $2 \times 10$ & $10-15$ & $1 \times 10$ & $20-25$ \\
\hline 9 & $3 \times 10$ & $20-25$ & $3 \times 10$ & $15-20$ & 0 & 0 & 0 & 0 \\
\hline 10 & $2 \times 10$ & $20-25$ & $2 \times 10$ & $15-20$ & $1 \times 10$ & $10-15$ & 0 & 0 \\
\hline 11 & $3 \times 10$ & $20-25$ & $3 \times 10$ & $15-20$ & $2 \times 10$ & $20-25$ & 0 & 0 \\
\hline 12 & $3 \times 10$ & $15-20$ & $2 \times 10$ & $20-25$ & $1 \times 10$ & $15-20$ & 0 & 0 \\
\hline 13 & $2 \times 10$ & $10-15$ & $1 \times 10$ & $10-15$ & 0 & 0 & 0 & 0 \\
\hline 14 & $3 \times 10$ & $15-20$ & $2 \times 10$ & $20-25$ & $1 \times 10$ & $10-15$ & 0 & 0 \\
\hline 15 & $3 \times 10$ & $20-25$ & $3 \times 10$ & $15-20$ & $2 \times 10$ & $20-25$ & 0 & 0 \\
\hline 16 & $2 \times 10$ & $10-15$ & $1 \times 10$ & $15-20$ & $1 \times 10$ & $10-15$ & 0 & 0 \\
\hline 17 & $2 \times 10$ & $15-20$ & $1 \times 10$ & $15-20$ & 0 & 0 & 0 & 0 \\
\hline 18 & $3 \times 10$ & $15-20$ & $2 \times 10$ & $20-25$ & $2 \times 10$ & $15-20$ & $1 \times 10$ & $20-25$ \\
\hline 19 & $3 \times 10$ & $20-25$ & $2 \times 10$ & $20-25$ & $1 \times 10$ & $15-20$ & $1 \times 10$ & $10-15$ \\
\hline 20 & $2 \times 10$ & $15-20$ & $1 \times 10$ & $15-20$ & $1 \times 10$ & $10-15$ & 0 & 0 \\
\hline 21 & $3 \times 10$ & $15-20$ & $2 \times 10$ & $20-25$ & 0 & 0 & 0 & 0 \\
\hline 22 & $2 \times 10$ & $20-25$ & $1 \times 10$ & $15-20$ & $1 \times 10$ & $10-15$ & 0 & 0 \\
\hline 23 & $3 \times 10$ & $20-25$ & $2 \times 10$ & $20-25$ & $2 \times 10$ & $15-20$ & 0 & 0 \\
\hline 24 & $3 \times 10$ & $15-20$ & $2 \times 10$ & $10-15$ & $1 \times 10$ & $10-15$ & 0 & 0 \\
\hline 25 & $2 \times 10$ & $10-15$ & $1 \times 10$ & $15-20$ & $1 \times 10$ & $10-15$ & $1 \times 10$ & $10-15$ \\
\hline 26 & $2 \times 10$ & $20-25$ & $1 \times 10$ & $15-20$ & $1 \times 10$ & $10-15$ & 0 & 0 \\
\hline 27 & $3 \times 10$ & $15-20$ & $2 \times 10$ & $20-25$ & $2 \times 10$ & $15-20$ & 0 & 0 \\
\hline 28 & $3 \times 10$ & $20-25$ & $2 \times 10$ & $20-25$ & $2 \times 10$ & $15-20$ & $1 \times 10$ & $20-25$ \\
\hline 29 & $2 \times 10$ & $10-15$ & $1 \times 10$ & $15-20$ & 0 & 0 & 0 & 0 \\
\hline 30 & $2 \times 10$ & $20-25$ & $1 \times 10$ & $15-20$ & 0 & 0 & 0 & 0 \\
\hline 31 & $2 \times 10$ & $20-25$ & $1 \times 10$ & $15-20$ & $1 \times 10$ & $10-15$ & $1 \times 10$ & $10-15$ \\
\hline 32 & $2 \times 10$ & $15-20$ & $1 \times 10$ & $15-20$ & $1 \times 10$ & $10-15$ & 0 & 0 \\
\hline 33 & $2 \times 10$ & $15-20$ & $1 \times 10$ & $10-15$ & 0 & 0 & 0 & 0 \\
\hline 34 & $3 \times 10$ & $15-20$ & $2 \times 10$ & $15-20$ & 0 & 0 & 0 & 0 \\
\hline 35 & $2 \times 10$ & $20-25$ & $1 \times 10$ & $10-15$ & 0 & 0 & 0 & 0 \\
\hline
\end{tabular}

Tabel 2 menunjukkan efektivitas Nifedipine, diantaranya pada pemberian terapi pertama banyak kontraksi selama 2x10 menit (durasi 10-15 detik) sebanyak 8 orang $(22.85 \%)$, $2 \times 10$ menit (durasi $15-20$ detik) sebanyak 10 orang (28.57\%), 2x10 menit (durasi 20-25 detik) sebanyak 3 orang(8.57\%), 3x10 menit (durasi 15-20 detik) sebanyak 9 orang $(25.71 \%)$, dan $3 \times 10$ menit (durasi 20-25 detik) sebanyak 5 orang $(14.28 \%)$. Pada pemberian terapi kedua, banyak kontraksi 1x10 menit (durasi 10-15 detik) sebanyak 8 orang (22.85\%), 1x10 menit (durasi 20-25 detik) sebanyak 27 orang $(77.14 \%)$ dan pemberian terapi ketiga dengan tidak ditemukan kontraksi sebanyak 33 orang (94.28\%).
Tabel 3 menunjukkan jumlah skala nyeri pada pasien ancaman persalinan prematur yaitu pemberian dosis terapi awal terdapat responden dengan skala nyeri 3 sebanyak 10 orang $(28.57 \%)$, skala nyeri 4 sebanyak 5 orang $(14.28 \%)$, skala nyeri 5 sebanyak 15 orang $(42.85 \%)$, skala nyeri 6 sebanyak 3 orang $(8.57 \%)$ dan skala nyeri 7 sebanyak 2 orang (5.71\%). Pemberian terapi ke dua terdapat responden dengan skala nyeri 1 sebanyak 12 orang (34.28\%), skala nyeri 2 sebanyak 10 orang (28.57\%) dan skala nyeri 3 sebanyak 7 orang (20\%) dan skala nyeri 4 sebanyak 6 orang $(17.14 \%)$. Setelah pemberian terapi ketiga terdapat responden dengan skala nyeri 0 sebanyak 30 orang $(85.71 \%)$, skala nyeri 1 sebanyak 3 orang (17.14\%) dan skala nyeri 2 sebanyak 2 orang $(5.71 \%)$. 
Tabel 3. Efektivitas Nifedipine terhadap Skala Nyeri Pre dan Post Terapi

\begin{tabular}{|c|c|c|c|c|}
\hline \multirow{3}{*}{ Kasus } & \multicolumn{4}{|c|}{ Skala Nyeri } \\
\hline & \multirow{2}{*}{$\begin{array}{l}\text { Pre- } \\
\text { terapi }\end{array}$} & \multicolumn{3}{|c|}{ Post Terapi } \\
\hline & & $\begin{array}{c}\mathrm{I}(3 \mathrm{x} 10 \\
\mathrm{mg} / 8 \mathrm{jam})\end{array}$ & $\begin{array}{c}\text { II (3 x } 10 \\
\mathrm{mg} / 8 \text { jam) }\end{array}$ & $\begin{array}{c}\text { III (3 x } 10 \\
\mathrm{mg} / 8 \text { jam) }\end{array}$ \\
\hline 1 & 5 & 4 & 2 & 1 \\
\hline 2 & 5 & 4 & 2 & 1 \\
\hline 3 & 4 & 2 & 1 & 0 \\
\hline 4 & 2 & 2 & 1 & 0 \\
\hline 5 & 5 & 3 & 2 & 0 \\
\hline 6 & 4 & 3 & 2 & 0 \\
\hline 7 & 4 & 3 & 2 & 0 \\
\hline 8 & 3 & 2 & 0 & 0 \\
\hline 9 & 2 & 2 & 0 & 0 \\
\hline 10 & 2 & 2 & 1 & 0 \\
\hline 11 & 5 & 3 & 2 & 1 \\
\hline 12 & 3 & 2 & 1 & 0 \\
\hline 13 & 4 & 3 & 1 & 0 \\
\hline 14 & 5 & 4 & 2 & 1 \\
\hline 15 & 3 & 2 & 1 & 0 \\
\hline
\end{tabular}

Pada tabel 4 menunjukkan data mengenai efek samping yang terjadi setelah pemberian terapi Nifedipine. Adapun efek samping yang diukur adalah Hipotensi (penurunan tekanan darah), udem, lemas, konstipasi dan sakit kepala. Dari data tersebut, dapat disimpulkan bahwa 7 pasien $(20 \%)$ dengan keluhan udem pada kaki, 2 pasien (5.71\%) dengan keluhan sakit kepala, 5 pasien (14.28\%) dengan keluhan lemas, 2 pasien $(5.71 \%)$ dengan keluhan konstipasi dan 19 pasien (54.28\%) tanpa keluhan.

Penelitian ini dilakukan dengan analisis deskriptif, sebanyak 35 sampel yang ditentukan berdasarkan rumus Slovin (10). Dilakukan di ruang perawatan obgyn Gedung Lontara 4 bawah di Rumah Sakit Dr. Wahidin Sudirohusodo Makassar, ruang rawat inap Baji Gau Rumah Sakit Umum Daerah Labuang Baji, RSIA Sitti Khadijah, dan Klinik Sitti Khadijah Makassar. Pengambilan data penelitian dilakukan pada pasien yang didiagnosis terancam bersalin prematur dengan usia kehamilan < 37 mingguyang dirawat periode bulan April - Juli 2016. Sampel adalah pasien ibu hamil yang masuk kategori inklusi yang dirawat di Lontara 4 bawah RS Dr. Wahidin Sudirohusodo sebanyak 11, ruang rawat inap Rumah Sakit Umum Daerah Labuang Baji sebanyak 7, RSIA Sitti Khadijah sebanyak 12, dan Klinik Sitti Khadijah Makassar sebanyak 5 orang dengan jumlah total sampel 35 pasien.

Penelitian dilakukan dengan cara pengisian inform consent oleh pasien sebagai kesediaan pasien menjadi sampel penelitian. Observasi pasien secara langsung dan wawancara dengan pasien secara non-formal. Selanjutnya, dilakukan pencatatan status pasien. Jenis data yang dikumpulkan selama penelitian meliputi karakteristik pasien (nama, usia, usia kehamilan), kondisi klinis pasien (hasil laboratorium, tanda-tanda vital).

Pada tabel menunjukkan jumlah responden yang berusia 20 - 35 tahun sebanyak 20 orangdan usia 36 - 45 tahun sebanyak 15 orang. Persalinan prematur mengalami peningkatan pada usia $<20$ tahun dan usia $>35$ tahun. Ibu usia muda mengalami peningkatan kejadian persalinan prematur lebih besar dibandingkan dengan ibu usia reproduksi (20-35 tahun). Kehamilan usia muda memungkinkan mengalami penyulit pada masa kehamilan dan persalinan karena memiliki pengetahuan yang terbatas tentang kehamilan atau kurangnya informasi dalam mengakses sistem pelayanan kesehatan. Pada usia ini, belum cukup dicapainya kematangan fisik, mental dan fungsi organ reproduksi dari calon ibu. Golongan primigravida muda dimasukkan dalam golongan resiko tinggi, karena angka kematian ibu dan bayi pada remaja 2-4 kali lebih tinggi dibandingkan dengan usia reproduksi.Persalinan prematur pada usia $>35$ tahun telah terjadi penurunan fungsi organ reproduksi, penurunan fungsi ini akan mempengaruhi kesehatan baik ibu maupun janin yang dikandungnya sehingga ibu dan bayi memiliki banyak faktor yang dapat mempersulit dan memperbesar risiko kehamilan (10).

\begin{tabular}{|c|c|c|c|}
\hline \multirow{3}{*}{ Kasus } & \multicolumn{3}{|c|}{ Efek Samping } \\
\hline & \multicolumn{3}{|c|}{ Dosis } \\
\hline & $I$ & II & III \\
\hline 1 & - & - & - \\
\hline 2 & - & - & UDEM \\
\hline 3 & - & - & - \\
\hline 4 & - & - & - \\
\hline 5 & - & - & - \\
\hline 6 & - & - & - \\
\hline 7 & - & - & - \\
\hline 8 & - & - & - \\
\hline 9 & - & - & SAKIT KEPALA \\
\hline 10 & - & - & - \\
\hline 11 & - & - & UDEM \\
\hline 12 & - & - & - \\
\hline 13 & - & - & - \\
\hline 14 & - & - & UDEM \\
\hline 15 & - & - & - \\
\hline 16 & - & - & - \\
\hline 17 & - & - & KONSTIPASI \\
\hline 18 & - & - & KONSTIPASI \\
\hline 19 & - & - & LEMAS \\
\hline 20 & - & - & UDEM \\
\hline 21 & - & - & - \\
\hline 22 & - & - & - \\
\hline 23 & - & - & LEMAS \\
\hline 24 & - & - & - \\
\hline 25 & - & - & - \\
\hline 26 & - & - & UDEM \\
\hline 27 & - & - & LEMAS \\
\hline 28 & - & - & - \\
\hline 29 & - & - & - \\
\hline 30 & - & - & UDEM LEMAS \\
\hline 31 & - & - & - \\
\hline 32 & - & - & - \\
\hline 33 & - & - & LEMAS \\
\hline 34 & - & - & UDEM \\
\hline 35 & - & - & SAKIT KEPALA \\
\hline
\end{tabular}

Dari tabel menunjukkan bahwa berat badan $<50 \mathrm{~kg}$ berjumlah 10 responden dan $\geq 50 \mathrm{~kg}$ berjumlah 25 responden. Kejadian persalinan prematur hampir 3 kali lebih tinggi pada ibu yang berat badannya kurang $50 \mathrm{~kg}$ pada saat hamil.

Jumlah gravidarum merupakan salah satu faktor predisposisi terjadinya kelahiran prematur karena jumlah paritas dapat mempengaruhi keadaan kesehatan ibu dalam kehamilan. Penyebab partus prematur antara lain karena faktor maternal yang salah satunya adalah faktor paritas. Berdasarkan penelitian menyatakan bahwa paritas dengan dengan kejadian partus prematur mempunyai hubungan 
yang bermakna, dimana pada wanita yang paritas lebih dari 3 ada kecenderungan mempunyai risiko sebesar 4 kali lebih besar untuk melahirkan bayi prematur bila dibandingkan dengan wanita yang paritasnya kurang dari 3.

Jumlah responden tanpa riwayat abortus sebanyak 3 orang, sedangkan pasien dengan riwayat abortus sebanyak 32 orang, sedangkan jumlah responden tanpa riwayat persalinan prematursebanyak 30 orang responden yang tidak memiliki riwayat partus prematur, dan 5 orang responden yang memiliki riwayat partus prematur. Riwayat abortus merupakan faktor yang berhubungan erat dengan persalinan prematur berikutnya. Ibu hamil yang pernah mengalami 1 kali persalinan prematur mempunyai resiko $37 \%$ untuk mengalami persalinan prematur dan ibu hamil yang pernah mengalami persalinan prematur 2 kali/lebih mempunyai resiko $70 \%$ untuk mengalami persalinan prematur selanjutnya. Insiden terjadinya persalinan prematur selanjutnya setelah $1 \mathrm{x}$ persalinan prematur meningkat hingga $14,3 \%$ dan setelah $2 x$ persalinan prematur meningkat hingga 28\%. Wanita yang mengalami persalinan prematur memiliki risiko untuk mengalaminya kembali pada kehamilan selanjutnya (10).

Berdasarkan tabel menunjukkan bahwa responden dengan pendidikan terakhir SD sebanyak 5 orang, pendidikan terakhir SMP sebanyak 7 orang, SMA sebanyak 13 orang, diploma sebanyak 5 orang dan Strata satu sebanyak 5 orang. Wanita pada tingkat sosial ekonomi (pekerjaan dan pendidikan) lebih rendah mempunyai kemungkinan 50\% lebih tinggi mengalami persalinan prematur dibandingkan dengan tingkat sosial ekonomi yang lebih tinggi. Frekuensi persalinan prematur hampir 2 kali lipat pada buruh kasar dibandingkan dengan yang terpelajar. Tinggi rendahnya tingkat pendidikan ibu erat kaitannya dengan tingkat pengertian terhadap perawatan kesehatan, higiene, dan perlunya pemeriksaan kehamilan. Rendahnya tingkat pendidikan dan kurangnya informasi yang menyebabkan masih banyaknya ibu-ibu yang kurang menyadari pentingnya pemeriksaan kehamilan menyebabkan tidak terdeteksinya faktor-faktor risiko tinggi yang mungkin dialami oleh mereka. Risiko ini baru diketahui pada saat persalinan yang sering kali karena kasusnya sudah terlambat sehingga dapat membawa akibat fatal. Sebagai akibat dari kurangnya kesadaran akan pentingnya pemeriksaan kehamilan dapat berdampak pada terjadinya persalinan prematur karena tidak terdeteksinya berbagai masalah kesehatan pada ibu. Dengan demikian, faktor pendidikan ibu merupakan salah satu determinan penting yang mempengaruhi kejadian kelahiran premature (10).

Dari 35 pasien yang mendapat terapi Nifedipine, 33 pasien yang berhasil menunda persalinan prematur dalam waktu 2x24 jam pada pemberian terapi ke 3,27 pasien yang berhasil menunda persalinan dengan penurunan kontraksi tersisa 1x10 menit (20-25 detik) dan 8 pasien yang berhasil menunda persalinan dengan penurunan kontraksi tersisa 1x10 menit (10-15 detik) masing-masing pada pemberian terapi ke 2. Dari hasil tersebut dapat disimpulkan bahwa, efektifitas nifedipine dalam menunda persalinan prematur dalam waktu 2x24 jam adalah sebesar 94.28\%.

Untuk terjadinya kontraksi harus terdapat kalsium bebas intraseluler yang cukup. Salah satu penyebab meningkatnya kadar kalsium intrasel adalah akibat pengaruh prostaglandin dalam hal ini dihasilkan oleh enzim cyclooxigenase. Nifedipine menghambat kerja enzim ini sehingga produksi prostaglandin akan menurun, kadar kalsium sel menurun dan kontraksi dihambat. Mekanisme penghambatan sistem COX2 lebih selektif sehingga diharapkan efek samping ke janin minimal (11).

\section{KESIMPULAN}

Faktor pemicu ancaman terhadap Partus prematur dapat disebabkan oleh beberapa faktor, meliputi ;Usia ibu, gravidarum , Tingkat pendidikan, Riwayat abortus dan Riwayat partus prematur. Nifedipine digunakan di Rumah Sakit Dr. Wahidin Sudirohusodo Makassar, Rumah Sakit Umum Daerah Labuang Baji, RSIA Sitti Khadijah, dan Klinik Sitti Khadijah Makassar efektif untuk mengurangi kontraksi dan menunda persalinan premature.

\section{DAFTAR PUSTAKA}

1. DEPKES RI. 2009

2. Kedokteran Fetomaternal POGI., Manajemen Persalinan Preterm. Bandung., Himpunan Kedokteran Fetomaternal POGI., 2011.

3. PROTOCOL TOCOLYTIC 2011

4. Joseph T. DiPiro, Barbara G. Wells, Terry L. Schwinghammer, Cecily V. DiPiro. Pharmacotherapy Handbook Seventh Edition., Mc Graw Hill Medical Columbia, 2009.

5. CHAN 2008

6. Neha Narang, Jyoti Sharma., Sublingual Mucosaasa route forsystemic Drug Delivery., International Journal of Pharmacy and Pharmaceutical Sciences, 2011.

7. Burkle, CM, Lanier, WL, and Wittich, CM. Ten Common Questions About Off-Label Drug Use. Mayo Clinic Proceedings, 2012

8. E. Kimland, V. Odlind, Off Lable Drug Use in Pediatric Patients., Medical Products Agency, Sweden., 2012

9. CONSUELLO

10. Jammeh, A., Sundby, J. \& Vangen, S. Maternal and obstetric risk factors for low birth weight and preterm birth in rural Gambia: a hospital-based study of 1579 deliveries Journal of Obstetrics and Gynecology., 2011

11. Gaspar Robert, Hajagos Judith., Calcium Channel Blockers as Tocolytics: Principles of TheirActions, Adverse Effects and Therapeutic Combinations., Pharmaceutical Hungary., 2013. 